Historic, archived document

Do not assume content reflects current scientific knowledge, policies, or practices. 

cop: 3 Agriculture

Forest Service

Intermountain

Research Station

Ogden, UT 84401

Research Paper

INT-355

December 1985

(405)

\section{Breeding Bird} Responses to Diameter-Cut Logging in West-Central Idaho

Dean E. Medin

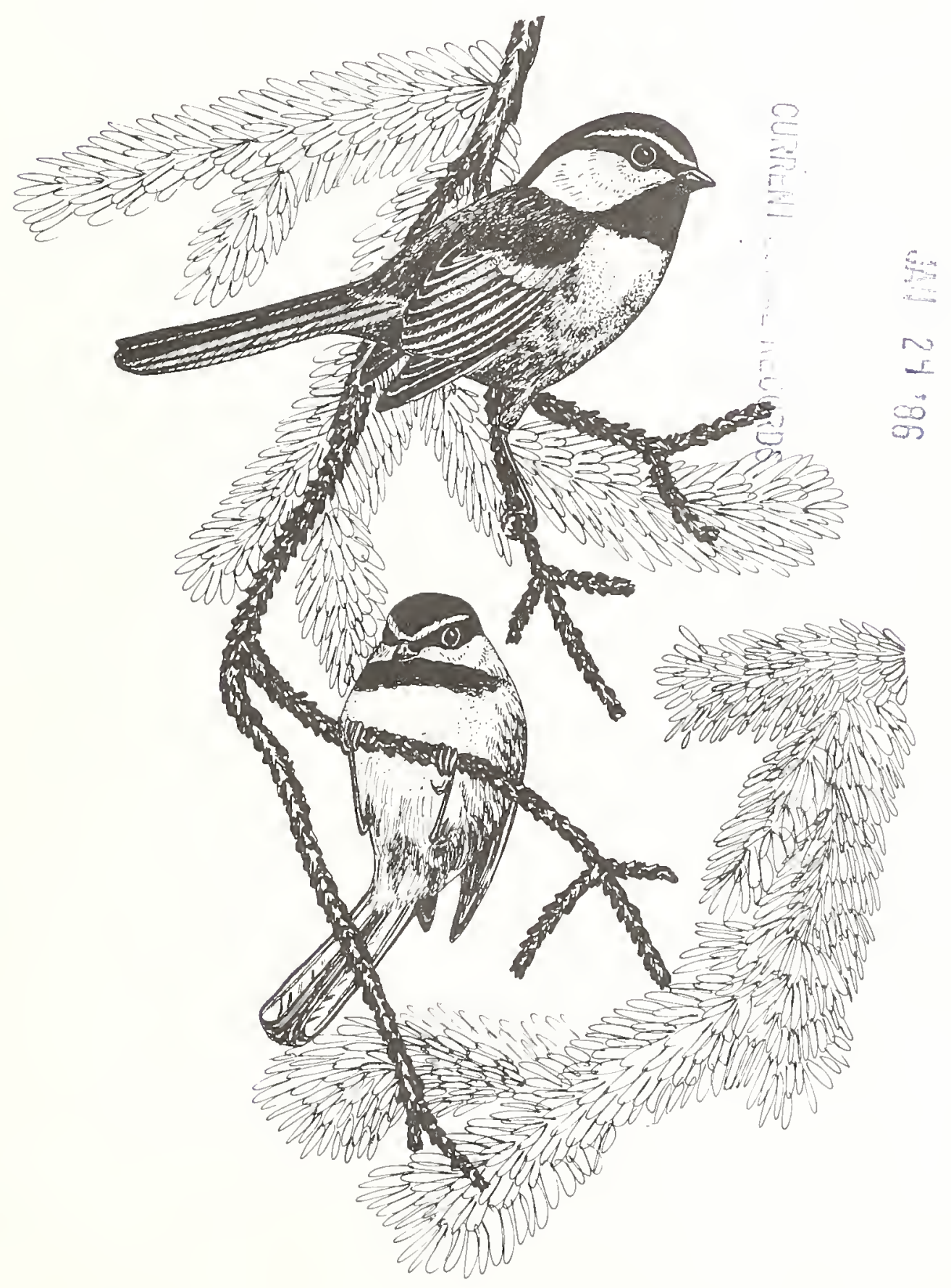




\section{THE AUTHOR}

DEAN E. MEDIN is a research wildlife biologist with the Intermountain Research Station at the Forestry Sciences Laboratory in Boise, ID. He earned a B.S. degree in forest management from lowa State University in 1957, an M.S. degree in wildlife management from Colorado State University in 1959, and a Ph.D. in range ecosystems from Colorado State University in 1976. His research assignments have included studies in mule deer ecology, big-game range improvement, big-game population modeling, and nongame bird ecology and habitat management.

\section{ACKNOWLEDGMENTS}

I gratefully acknowledge the valuable field and office assistance of James R. Groves, Robert Jordan, Stan Baker, and Shiela Donovan. James F. Rathbun, District Ranger, Boise National Forest, arranged for part-time housing facilities near the study site. Walter F. Megahan, James L. Clayton, Timothy L. Mosko, Dale O. Hall, and Russell A. Ryker, Forestry Sciences Laboratory, Boise, ID, provided support and contributed in many other ways.

\section{RESEARCH SUMMARY}

Populations of breeding birds responded differently to structural changes in a Douglas-fir forest caused by diameter-cut logging. Little change occurred in total bird density or standing crop biomass of birds either between years or between logged and unlogged plots. But there were pronounced changes in the composition of the breeding bird community. Logging the forest resulted in increases in numbers for species that require more open habitats and decreases in populations for species that require more closed habitats. Several species maintained relatively stable densities on both logged and unlogged plots.

The number of breeding bird species (species richness) was consistently higher on logged plots than on unlogged plots and trended upward each year after logging. Ten species were territorial only in the logged forest. One species that was territorial in the unlogged forest was absent from the logged forest. There were no clear patterns in bird species diversity either between years or between logged and unlogged plots. The evenness (equitability) component of bird species diversity declined each year after logging.

Two categories (guilds) of birds-the foliage foragers and the timber gleaners-were less numerous on logged plots. The timber-gleaning guild, the most severely affected, dropped to only one-third of prelogging densities in the third year after logging. The ground-foraging and flycatching guilds were more numerous on logged plots. Of nine species represented in the ground-foraging guild, each was proportionately more abundant in the logged forest than in the unlogged forest. The timber-drilling guild, at least in total, was a relatively stable component of the breeding bird population.

Patterns observed in this study, and other studies that were compared, suggest consistencies of response among certain breeding bird species to logging in western coniferous forests. 


\title{
Breeding Bird Responses to Diameter-Cut Logging in West-Central Idaho
}

\author{
Dean E. Medin
}

\section{INTRODUCTION}

The structure of forest vegetation is an important bird niche dimension (Anderson and Shugart 1974; Conner and others 1983; James 1971; Karr and Roth 1971; MacArthur 1964; Morrison and Meslow 1983b; Willson 1974). Alterations in structure caused by logging produce changes in the organization of associated bird communities (Blake 1982; Conner and Adkisson 1975; DeByle 1981; Franzreb and Ohmart 1978; Hagar 1960; Kilgore 1971; Maurer and others 1981; Morrison and Meslow 1983a; Scott and Gottfried 1983; Strelke and Dickson 1980; Szaro and Balda 1979; Titterington and others 1979; Webb and others 1977).

Diameter-cut logging is the removal of all merchantable trees above a specified diameter breast height (d.b.h.)(Ford-Robertson 1971). This study examined relationships between breeding birds and a commercial diameter-cut in a Douglas-fir forest in westcentral Idaho. The objective was to quantitatively assess the effects of the logging on breeding bird populations and community organization. All tree stems greater than 10 inches $(25 \mathrm{~cm})$ d.b.h. were felled within defined cutting units. Logging began in September and was completed in November 1976.

\section{STUDY AREA}

The study was made on two forested experimental watersheds in the Silver Creek drainage, a tributary of the Middle Fork of the Payette River. The area is about 56 miles $(90 \mathrm{~km})$ northeast of Boise in Valley County, ID. Watershed SC-6, about 403 acres (163 ha) in size, was partially logged in three separate blocks; watershed SC-3, about 319 acres (129 ha), served as an unlogged control.

Watershed slopes are steep, dissected, and face southeast. Soils are weakly developed and underlain by granitic bedrock. Annual precipitation in the area averages about 32 inches $(80 \mathrm{~cm})$; a large portion occurs as snowfall (Megahan and Clayton 1983).

Douglas-fir (Pseudotsuga menziesii var. glauca) and ponderosa pine (Pinus ponderosa) are the dominant overstory trees, with scattered stands of grand fir (Abies grandis), lodgepole pine (Pinus contorta), and Engelmann spruce (Picea engelmannii). Mallow ninebark (Physocarpus malvaceous) and white spiraea (Spiraea betulifolia) normally dominate the shrubby undergrowth, but Scouler willow (Salix scouleriana), Rocky Mountair maple (Acer glabrum), snowberry (Symphoricarpos spp.). and common chokecherry (Prunus virginiana) are often present. Many forbs and graminoids occupy the ground layer.

Two habitat types (Steele and others 1981) are mainly represented: Douglas-fir/ninebark, ponderosa pine phase, and Douglas-fir/white spiraea, ponderosa pine phase.

\section{LOGGING PROCEDURE}

Trees on watershed SC-6 were cut commercially to a 10-inch $(25-\mathrm{cm})$ minimum diameter (breast height) in three separate and well-spaced cutting units (fig. 1). The units, topographically defined and irregularly elongate in outline, were 20,22 , and 45 acres $(8,9$, and 18 ha). Uncut buffer strips bordered the cutting units, averaging $50 \mathrm{ft}(15 \mathrm{~m})$ to first- or second-order stream channels, and $100 \mathrm{ft}(30 \mathrm{~m})$ to the third-order (main) stream channel. All cutting units were on southerly aspects. Logs were yarded by helicopter to minimize site damage. Slash was lopped, scattered, and then broadcast burned. An estimated 80 percent of the slash was effectively burned.

\section{STUDY METHODS}

Two 20-acre (8-ha) study plots were established on watershed SC-6 before logging; plot 1 was located within the largest cutting unit; plot 2 was located within the smallest unit. A third 20-acre (8-ha) study plot was established on watershed SC-3 to serve as an unlogged control. Birds were censused and otherwise studied each year on all three of the study plots beginning in 1976 (prelogging) and ending in 1979 (third-year postlogging). Overstory (tree) vegetation was sampled on the cutting units before logging in 1976 and after logging in 1977. Understory vegetation (shrubs, forbs, graminoids) was sampled in 1976 (prelogging) and variously thereafter until 1981 (fifth-year postlogging).

\section{Overstory Vegetation}

Overstory vegetation data and methodology are from Geier-Hayes and Ryker (1983). A surveyed and marked 650 - by 650 -ft (200- by $200-\mathrm{m}$ ) grid system was superimposed on the experimental watersheds. Grid coordinates were used to permanently reference sampling locations. Nine sample points, each equidistant from the other, were located in each grid square. Overstory data were derived from sample points that were located within cutting unit boundaries. 


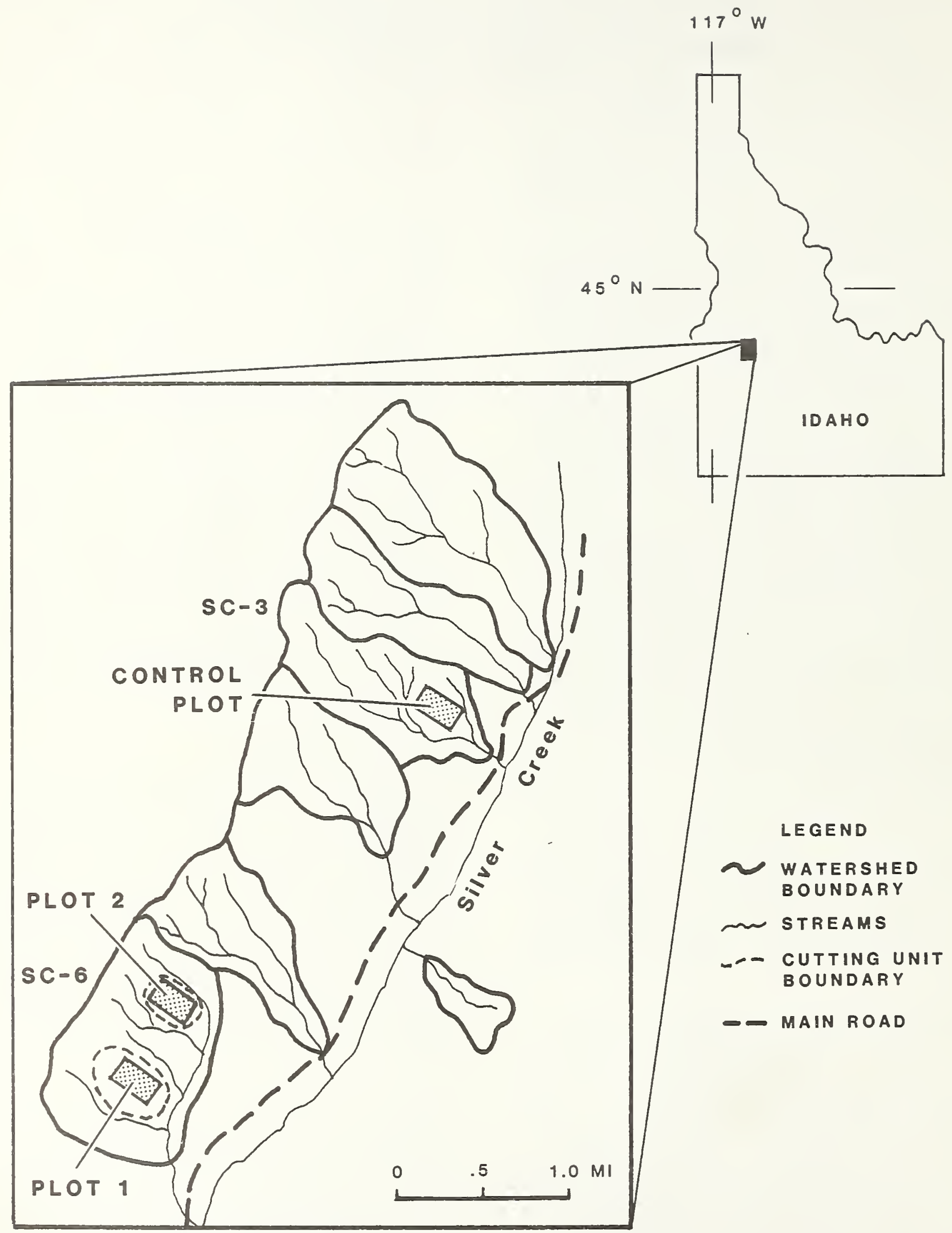

Figure 1.- Location of study plots on two small experimental watersheds of Silver Creek drainage, west.central ldaho. 
From each sample point, 72.6 -ft $(22.1-\mathrm{m})$ lines were measured in each cardinal direction. Ten milacre (0.0004-ha) quadrats were established along each line to record tree seedling, sapling, and pole frequency and density by either height class (seedlings) or diameter class (saplings and poles). The center of a variable-radius plot was located at the midpoint of each line. Diameter (breast height), height, and other data were measured for each sample tree selected by use of an angle gauge.

\section{Understory Vegetation}

Sampling procedures followed Daubenmire and Daubenmire (1968). A 49 - by 82 -ft (15- by $25-\mathrm{m})$ macroplot was located at each of four sampling sites within each cutting unit. Two 82 -ft $(25-\mathrm{m})$ transects were placed perpendicular to the short axis of the macroplot. Forb and graminoid frequency and canopy coverage data (Daubenmire 1959) were collected from 7.87- by 19.68-inch (20- by $50-\mathrm{cm}$ ) microplots (50 plots) placed at 3.28 -ft $(1-\mathrm{m})$ intervals along the transects. Canopy coverage for each species was recorded as the midpoint of one of seven coverage classes $(0-0.5,0.5-5,5-25,25-50$, 50-75, 75-95, and 95-100 percent).

Fifty three-dimensional plots ( 3.28 by 3.28 by $9.84 \mathrm{ft}$; 1 by 1 by $3 \mathrm{~m}$ ) placed contiguous to the microplcts were used to estimate shrub canopy coverage and shrub canopy vclume (Zamora 1981). Shrub canopy volume for each species was recorded as the midpoint of one of eight volume classes $(0-1,1-5,5-10,10-25,25-50,50-75$, 75-95, and 95-100 percent). Shrub canopy coverage classes were the same as those used for forbs and graminoids.

\section{Breeding Birds}

The 20-acre (8-ha) plots were censused for breeding birds using the Williams spot-map method (International
Bird Census Committee 1970). Methodological difficulties and other special problems of the mapping method are summarized by Oelke (1981). Plots varied in shape from square to rectangular depending on terrain and cutting unit boundaries. Plots were surveyed and gridded in a Cartesian coordinate system with points flagged and numbered with stakes at $164-\mathrm{ft}(50-\mathrm{m})$ intervals. At least 10 census visits were made annually to each plot from mid-May to late July from 1976 through 1979. Most of the work was done from sunrise to late morning when birds were most active. To ensure complete coverage, the plot was censused by walking within $82 \mathrm{ft}(25 \mathrm{~m})$ of all points on the grid. Observations extended well beyond plot boundaries.

At the end of the sampling period, concentrated groups of observations were circled as indicating areas of activity or approximate territories. Fractional parts of boundary territories were recognized. Results were converted to the number of pairs of breeding birds per 100 acres (40.5 ha).

Estimates of bird species diversity and the evenness component followed Hill (1973). Diversity was estimated as

$$
\mathrm{N}_{2}=1 / \Sigma \mathrm{pi}^{2}
$$

where $p_{i}$ is the proportion of the collection belonging to the ith species in the sample. Species richness $\left(\mathrm{N}_{0}\right)$ was expressed as the total number of territorial species observed on a plot. Evenness was calculated using the ratio

where

$$
\mathrm{E}=\mathrm{N}_{2} / \mathrm{N}_{1}
$$

$$
\mathrm{N}_{1}=\exp \left(-\Sigma \mathrm{p}_{\mathrm{i}} \ln \mathrm{p}_{\mathrm{i}}\right)
$$

\begin{tabular}{|c|c|c|c|c|}
\hline \multirow[b]{2}{*}{ Feature } & \multicolumn{2}{|c|}{ Plot 1} & \multicolumn{2}{|c|}{ Plot 2} \\
\hline & Prelogging & Postlogging & Prelogging & Postlogging \\
\hline Basal area $\left(\mathrm{ft}^{2} / \mathrm{acre}\right)$ & 90 & 22 & 117 & 24 \\
\hline Stand volume, live tree $\left(\mathrm{ft}^{3} / \mathrm{acre}\right)$ & 3,013 & 43 & 3,407 & 232 \\
\hline Stand volume, dead tree ( $\left.\mathrm{ft}^{3} / \mathrm{acre}\right)$ & 61 & 0 & 192 & 8 \\
\hline Tree density (no./acre) $)^{2}$ & 29.3 & 1.9 & 37.5 & 9.8 \\
\hline Pole density (no./acre) ${ }^{3}$ & 96 & 71 & 101 & 84 \\
\hline \multicolumn{5}{|l|}{ Canopy coverage (percent) } \\
\hline Shrubs & 46.0 & 24.7 & 56.5 & 32.0 \\
\hline Forbs & 26.2 & 22.4 & 23.9 & 21.3 \\
\hline Graminoids & 14.9 & 18.0 & 18.6 & 25.9 \\
\hline Annuals & .02 & 4.76 & 0 & 3.50 \\
\hline Shrub canopy volume $\left(\mathrm{ft}^{3}\right)^{4}$ & 3.32 & 4.62 & 13.81 & 7.64 \\
\hline
\end{tabular}

Table 1. - Features of the vegetation on bird study plots before and after logging, 1976-781

\footnotetext{
${ }^{1}$ Prelogging sampling was done in 1976; postlogging tree sampling was done in 1977; postlogging understory sampling was done in 1978. Data from Geier-Hayes and Ryker (1983).

${ }^{2}$ Trees $>10$ inches $(25 \mathrm{~cm})$ d.b.h.

${ }^{3}$ Trees $<10$ inches $(25 \mathrm{~cm})$ d.b.h

${ }^{4}$ Based on plot size of 3.28 by 3.28 by $9.84 \mathrm{ft}$ ( 1 by 1 by $3 \mathrm{~m}$ ).
} 


\section{RESULTS AND DISCUSSION}

\section{Vegetation}

Tree density, including all age classes, varied from 125 to 138 stems per acre ( 309 to 342 stems per ha) on bird study plots (cutting units) before logging (table 1). Trees remaining after logging, mostly pole-sized and clumped in distribution, ranged from 73 to 94 stems per acre (180 to 231 stems per ha). Few snag (dead) trees remained after logging. Prelogging stand basal area on the cutting units was 90 and $117 \mathrm{ft}^{2}$ per acre $\left(20.7\right.$ and $26.8 \mathrm{~m}^{2}$ per ha); residual basal area was 22 and $24 \mathrm{ft}^{2}$ per acre (5.1 and $5.5 \mathrm{~m}^{2}$ per ha). Volume of timber removed by logging averaged $3.072 \mathrm{ft}^{3}$ per acre $\left(215 \mathrm{~m}^{3}\right.$ per ha). This represents a reduction of 78 percent in basal area and 95 percent in stand volume.

Shrubs were the dominant feature of the understory layer (table 1). Shrub canopy cover values, high before logging, were reduced after logging and slash burning. Both pre- and postlogging shrub canopy cover and volume were dominated by ninebark and white spiraea. Grass and grasslike species, particularly pinegrass (Calamagrostis rubescens), showed increases in cover 2 years after logging. Annuals, mostly littleflower collinsia (Collinsia parviflora), increased. Shrubs and herbs had a combined average canopy cover of 93 percent before logging and 76 percent 2 years after logging.

\section{Breeding Birds, Unlogged Forest}

The density of breeding birds occupying the unlogged forest ranged from 189 to 214 pairs per 100 acres (40.5 ha) on the different plots during the 4-year study (table 2). From 18 to 22 species were territorial. The most abundant species, each making up more than 5 percent of the breeding bird community and collectively accounting for 70 percent, were:

Swainson's thrush

western tanager

dark-eyed junco

red-breasted nuthatch

chipping sparrow

Empidonax flycatcher

mountain chickadee

MacGillivray's warbler

(Scientific names are in table 2.)

Other common birds in the unlogged forest were:

yellow-rumped warbler

calliope hummingbird

solitary vireo

American robin

brown creeper

Cassin's finch

hairy woodpecker
Numerically, hole-nesting species made up 22 percent of the breeding bird community. These were:

northern flicker

hairy woodpecker

white-headed woodpecker

mountain chickadee

white-breasted nuthatch

red-breasted nuthatch

brown creeper

When expressed as standing crop biomass, Swainson's thrush was the predominant species, followed by the western tanager, American robin, northern flicker, darkeyed junco, hairy woodpecker, and chipping sparrow. Those seven species comprised 68 percent of the standing crop biomass of the breeding birds. Total standing crop biomass on unlogged study plots ranged from 81 to 89 grams per acre (199 to 219 grams per ha).

In addition to the 35 breeding bird species listed in table 2 , others commonly observed on or flying above the study plots were:

sharp-shinned hawk (Accipiter striatus)

northern goshawk (Accipiter gentilis)

red-tailed hawk (Buteo jamaicensis)

American kestrel (Falco sparverius)

spruce grouse (Dendragapus canadensis)

ruffed grouse (Bonasa umbellus)

gray jay (Perisoreus canadensis)

common raven (Corvus corax)

red crossbill (Loxia curvirostra)

Other species observed less frequently on the study plots included:

turkey vulture (Cathartes aura)

Cooper's hawk (Accipiter cooperii)

golden eagle (Aquila chrysaetos)

blue grouse (Dendragapus obscurus)

mourning dove (Zenaida macroura)

great horned owl (Bubo virginianus)

northern pygmy owl (Glaucidium gnoma)

rufous hummingbird (Selasphorus infus)

Williamson's sapsucker (Sphyrapicus thyroideus)

downy woodpecker (Picoides pubescens)

three-toed woodpecker (Picoides tridactylus)

pileated woodpecker (Dryocopus pileatus)

Steller's jay (Cyanocitta stelleri)

Clark's nutcracker (Nucifraga columbiana)

varied thrush (Ixoreus naevius)

lazuli bunting (Passerina amoena)

song sparrow (Melospiza melodia)

brown-headed cowbird (Molothrus ater)

pine grosbeak (Pinicola enucleator)

evening grosbeak (Coccothraustes vespertinus) 


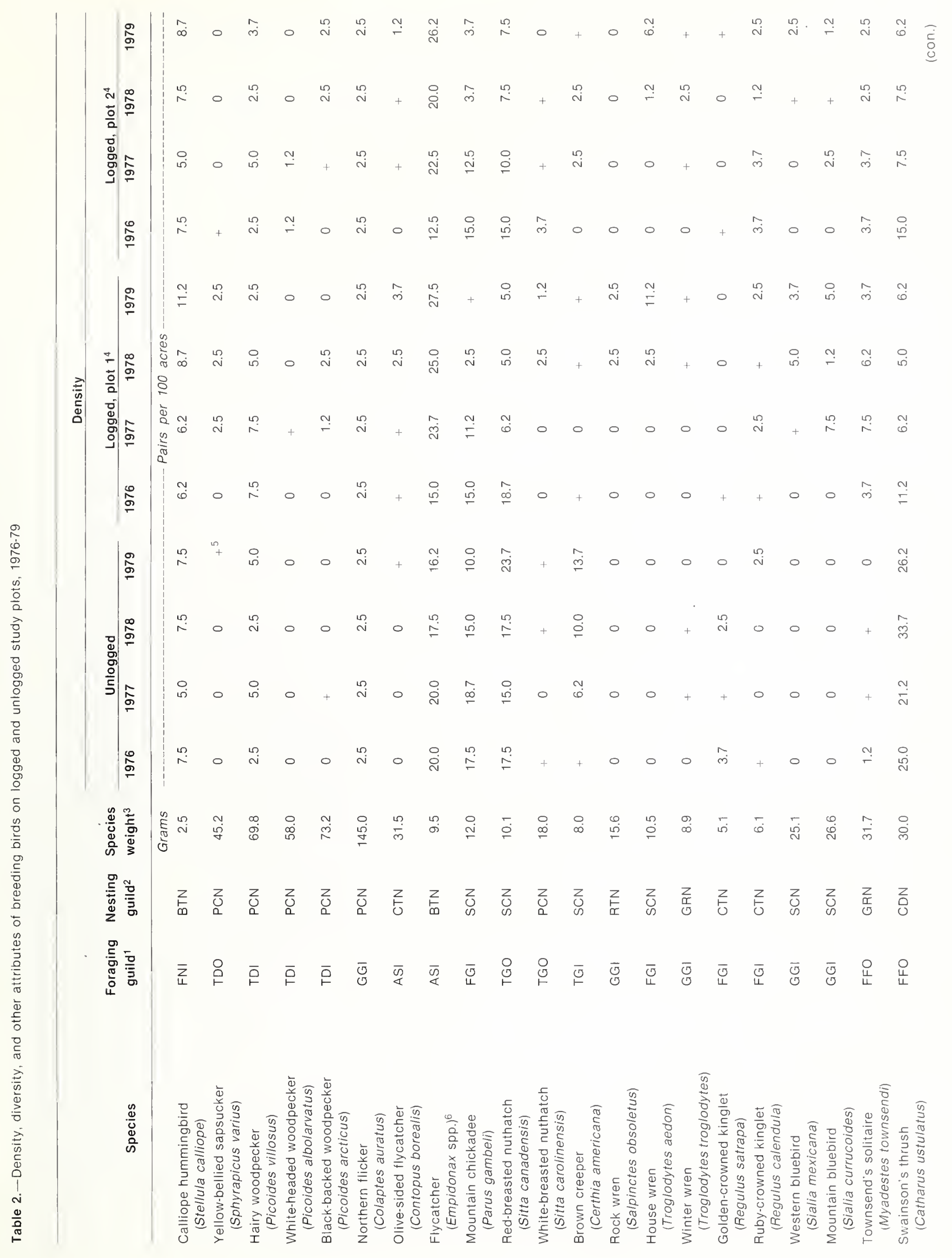




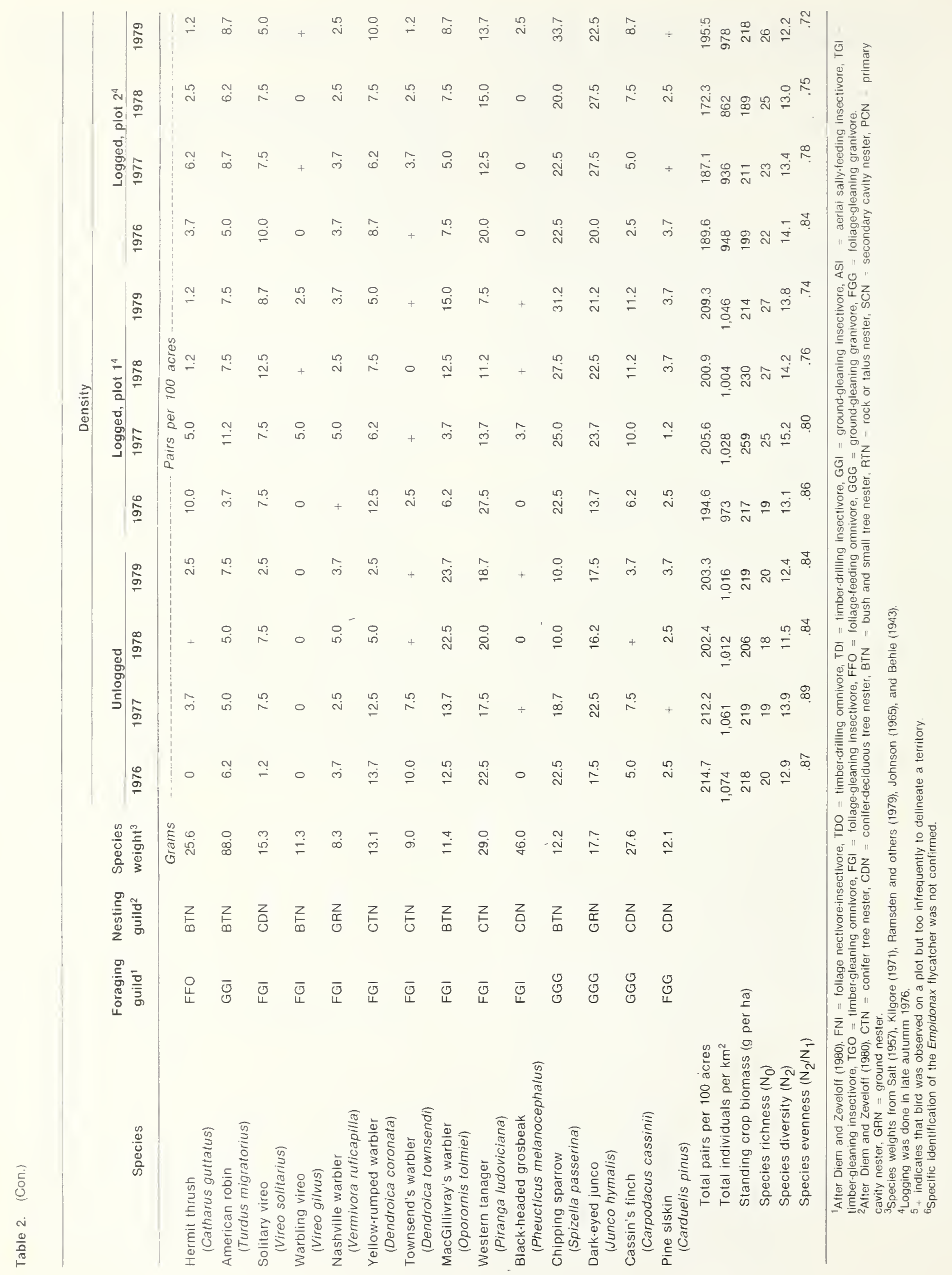




\section{Breeding Birds, Logged Forest}

Breeding bird density ranged from 172 to 209 pairs per 100 acres ( $40.5 \mathrm{ha}$ ) on logged study plots; 23 to 27 species were territorial (table 2). The most common species, each making up more than 5 percent of the breeding bird population, were:

chipping sparrow
dark-eyed junco
Empia'onax flycatcher
western tanager
Other common species were:
Cassin's finch
MacGillivray's warbler
American robin
solitary vireo
calliope humminghird
yellow-rumped warbler
red-breasted nuthatch
Swainson's thrush

Those 12 species accounted for 76 percent of the breeding bird community.

In standing crop biomass, the American robin was the leading species followed by the dark-eyed junco, northern flicker, western tanager, chipping sparrow, hairy woodpecker, and Cassin's finch. Those seven species made up 62 percent of the standing crop biomass in the logged forest. Total standing crop biomass on logged plots ranged from 76 to 105 grams per acre (189 to 259 grams per ha).

Hole-nesting species accounted for 16 percent of the breeding bird density on logged plots compared to the 22 percent found on unlogged plots. Most of the difference in hole-nester density resulted from reduced abundance of the red-breasted nuthatch, mountain chickadee, and brown creeper on logged areas. The hairy woodpecker, northern flicker, and white-breasted nuthatch had similar densities on both logged and unlogged plots.

Species richness was generally lowest on unlogged plots and highest on logged plots (table 2). When compared with the unlogged control plot, annual bird species richness values trended consistently upward on the logged areas. Year-to-year variation in the number of territorial species on the unlogged control plot was slight. The evenness (equitability) component of species diversity tended to decline each year in postlogging environments. No consistent annual trend in species evenness was noted on the unlogged control plot. No clear patterns were apparent between years or between logged and unlogged plots with respect to bird species diversity.

\section{Species Responses}

Although breeding bird density and standing crop biomass totals in the unlogged and logged forest were similar, there were important changes in the composition of the bird community on logged plots (table 2).
Twenty-five species established territories on unlogged plots during the study; 34 species were territorial on logged plots.

Ten of the breeding bird species found in the logged forest were not present before logging; these included the house wren, mountain bluebird, western bluebird, black-backed woodpecker, yellow-bellied sapsucker, olive-sided flycatcher, warbling vireo, and black-headed grosbeak. All of the newly territorial species attracted to logged areas occurred in low densities. Among the species that were territorial in the unlogged forest, only the golden-crowned kinglet was absent from logged study plots.

In addition to those species attracted to logged plots, several others appeared to react positively to structural changes in the vegetation caused by timber cutting. Species with higher densities after logging included the Empidonax flycatcher, Townsend's solitaire, American robin, chipping sparrow, dark-eyed junco, and Cassin's finch. Of these, only the Cassin's finch nested in the overstory; the others nested either on the ground or in the understory layer (Medin 1985). Each of the six species or genera have been classified by Thomas (1979) as having medium or high versatility ratings with respect to reproductive and feeding orientation. All but the Empidonax flycatcher are characteristic of ecotonal habitats. The American robin, chipping sparrow, darkeyed junco, Cassin's finch, and Empidonax flycatcher are widespread breeding species in the coniferous forests of central Idaho.

Seven species responded negatively to the logging. These were:
mountain chickadee
red-breasted nuthatch
brown creeper
Swainson's thrush
Townsend's warbler
MacGillivray's warbler
western tanager

Three species-the mountain chickadee, red-breasted nuthatch, and brown creeper-are secondary cavity nesters. All but the MacGillivray's warbler are found in old-growth habitats (Thomas 1979). The brown creeper nests under loose bark and is often associated with mature stands of ponderosa pine. The Townsend's warbler is a species characteristic of multiple canopy, mature, and old-growth true fir and mixed conifer stands.

Densities of other breeding bird species listed in table 2 were similar on both logged and unlogged plots. The most numerous of these included the calliope humming. bird, hairy woodpecker, northern flicker, hermit thrush, solitary vireo, Nashville warbler, yellow-rumped warbler, and pine siskin. Incongruently, three of these speciesthe hairy woodpecker, hermit thrush, and Nashville warbler-were given low versatility scores by Thomas (1979).

Five woodpecker species (yellow-bellied sapsucker, hairy woodpecker, white-headed woodpecker, blackbacked woodpecker, and northern flicker) were territorial on one or both of the logged plots during the study 
(table 2). Although there were few snag trees remaining immediately after logging, the slash-burning treatment conducted weeks later killed or damaged many of the residual unmerchantable trees. The highest woodpecker densities recorded during the study were on logged plots the year following logging and slash burning. Some, but not all, of the territorial woodpeckers nested directly on the logged plots. Hagar (1960) also noted increased woodpecker densities on recently logged areas in northwestern California.

The presence of relatively high numbers of woodpeckers on logged plots resulted in a number of holes being excavated in dead or weakened residual trees which, in turn, provided nest sites for the western bluebird, mountain bluebird, and house wren. Frequent and prolonged combative encounters between wrens and bluebirds near excavated or natural tree cavities suggested competition for nest sites on logged plots. Recently dead and trunk-blackened trees, particularly Douglas-fir, were used heavily by the black-backed woodpecker for feeding and, in two cases, for nest sites. The pileated woodpecker, an uncommon bird in the area, was rarely observed on logged plots.

Table 3 summarizes responses of common bird species to tree removal treatments in coniferous forests of the western United States. The notations in table 3 represent a liberal interpretation of published information that was often originally presented in tabular form. Source material is arrayed left to right roughly on the basis of the degree of tree removal with the most severe treatment on the extreme right. Twelve species tended to react positively to most tree removal treatments. These were:
olive-sided flycatcher
rock wren
house wren
winter wren
western bluebird
mountain bluebird
American robin
rufous-sided towhee
chipping sparrow
fox sparrow
dark-eyed junco
Cassin's finch

The wrens, bluebirds, and sparrows were consistent in showing an upward numerical response. Nine species responded negatively to most treatments. These were:

western flycatcher

mountain chickadee

red-breasted nuthatch

pygmy nuthatch

brown creeper

golden-crowned kinglet

hermit thrush

Townsend's warbler

red-faced warbler
Responses of other species listed in table 3 are less clear. The hairy woodpecker, northern flicker, Townsend's solitaire, yellow-rumped warbler, and pine siskin either responded minimally or were inconsistent in their response to treatment except for the highest levels of tree removal. In general, the numerical response of many species depends on the degree of tree removal; compare, for example, species responses listed from Kilgore (1971) with those from the clearcut treatment of Szaro and Balda (1979).

\section{Guild Responses}

Birds may be placed in categories, or guilds, based on foraging behavior or the type of substrate in which foraging occurs (Diem and Zeveloff 1980; Root 1967). The 35 breeding bird species listed in table 2 were divided into five foraging guilds: foliage foragers, flycatchers, timber drillers, timber gleaners, and ground foragers (table 4).

Birds that forage by searching foliage (foliage foragers) formed the largest single category, and these, along with the ground foragers, made up the largest proportion of all foraging categories. Among the foliage foragers, insectivorous species predominated. The ground-foraging forms, which included chipping sparrows, dark-eyed juncos, and Cassin's finches, were largely granivorous. The flycatchers were the olive-sided flycatcher and the Empidonax flycatcher. Four species-the yellow-bellied sapsucker, hairy woodpecker, white-headed woodpecker, and black-backed woodpecker-were classified as timber drillers, and three species-the red-breasted nuthatch, white-breasted nuthatch, and brown creeper-were grouped as timber gleaners.

Foliage foragers (17 species) had the highest total density of all foraging guilds in the unlogged forest (table 4). The three species with the highest densities were the Swainson's thrush, western tanager, and mountain chickadee. The foliage foraging guild declined after logging. One species, the golden-crowned kinglet, was territorial only on unlogged plots. Three foliage foragers (house wren, warbling vireo, and black-headed grosbeak) were territorial only on logged plots.

Birds that forage by gleaning the surface of bark (timber gleaners) declined the most after logging; guild density in the third year following logging was only about one-third that of prelogging density. The numerical decrease was most severe for the brown creeper and red-breasted nuthatch. Other foraging guilds-the ground foragers and flycatchers-were more numerous on logged plots. Birds that feed on the ground were, by a slight margin, the most abundant foraging guild on logged plots 3 years after logging. Each of the nine species in the ground-foraging guild was proportionately more abundant in logged environments than in the unlogged forest. The timber-drilling guild maintained relatively stable total densities on both logged and unlogged plots.

Categorizing birds on the basis of the substrate in which nesting occurs provides additional information about the breeding bird community. Six nesting guilds were recognized: conifer tree, conifer-deciduous tree, 
Table 3.- Responses of common bird species to tree removal in western coniferous forests. Upward-pointing arrows (1) indicate a positive numerical response; downward-pointing arrows ( $)$ indicate a negative numerical response; horizontal arrows ( - ) indicate a minimal numerical response

\begin{tabular}{|c|c|c|c|c|c|c|c|c|c|c|}
\hline \multirow[b]{2}{*}{ Species } & \multicolumn{10}{|c|}{ Source, treatment, and location } \\
\hline & $\begin{array}{c}\text { Kilgore } \\
\text { (1971) } \\
\text { Understory } \\
\quad \text { fuel } \\
\text { reduction } \\
\text { CA }\end{array}$ & $\begin{array}{l}\text { Mannan } \\
\text { and } \\
\text { Meslow } \\
\text { (1984) } \\
\text { Thinning } \\
\text { OR }\end{array}$ & $\begin{array}{c}\text { Szaro } \\
\text { and } \\
\text { Balda } \\
\text { (1979) } \\
\text { Shelterwood } \\
\text { AZ }\end{array}$ & $\begin{array}{c}\text { Scott } \\
\text { and } \\
\text { Gottfried } \\
(1983) \\
\text { Various } \\
\text { AZ }\end{array}$ & $\begin{array}{l}\text { Scott } \\
\text { and } \\
\text { others } \\
(1982) \\
\text { Patch } \\
\text { clearcut } \\
\text { CO }\end{array}$ & $\begin{array}{l}\text { This } \\
\text { study } \\
\text { Diameter } \\
\text { cut } \\
\text { ID }\end{array}$ & $\begin{array}{c}\text { Franzreb } \\
\text { and } \\
\text { Ohmart } \\
(1978) \\
\text { Selection } \\
\text { AZ }\end{array}$ & $\begin{array}{c}\text { Clearcut } \\
\text { CA }\end{array}$ & $\begin{array}{c}\text { Clearcut } \\
\mathrm{AZ}\end{array}$ & $\begin{array}{c}\text { Szaro } \\
\text { and } \\
\text { Balda } \\
\text { (1979) } \\
\text { Clearcut } \\
\text { AZ }\end{array}$ \\
\hline $\begin{array}{l}\text { Broad-tailed hummingbird } \\
\text { (Selasphorus platycercus) }\end{array}$ & & & 1 & & & & - & & 1 & 1 \\
\hline Yellow-bellied sapsucker & $\rightarrow$ & $\rightarrow$ & & & & $\uparrow$ & 1 & $\rightarrow$ & $!$ & \\
\hline Williamson's sapsucker & & 1 & & 1 & - & & - & & & \\
\hline Hairy woodpecker & - & $\rightarrow$ & 1 & 1 & 1 & $\rightarrow$ & $\rightarrow$ & $\dagger$ & - & 1 \\
\hline White-headed woodpecker & - & - & & & & $\rightarrow$ & & $\rightarrow$ & & \\
\hline Black-backed woodpecker & & $\rightarrow$ & & & & 1 & & & & \\
\hline Northern flicker & $\rightarrow$ & $\rightarrow$ & $\rightarrow$ & $\rightarrow$ & $\rightarrow$ & $\rightarrow$ & - & 1 & 1 & 1 \\
\hline Olive-sided flycatcher & $\rightarrow$ & & & & 1 & 1 & 1 & $\uparrow$ & & \\
\hline $\begin{array}{l}\text { Western flycatcher } \\
\text { (Empidonax difficilus) }\end{array}$ & & & 1 & 1 & - & & 1 & t & & 1 \\
\hline Steller's jay & - & $\rightarrow$ & 1 & 1 & & & $\rightarrow$ & $\uparrow$ & 1 & 1 \\
\hline Mountain chickadee & - & - & $\rightarrow$ & $\rightarrow$ & 1 & $!$ & 1 & 1 & 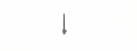 & 1 \\
\hline Red-breasted nuthatch & - & 1 & & 1 & 1 & $!$ & 1 & $!$ & & \\
\hline White-breasted nuthatch & & $\rightarrow$ & 1 & - & & $\rightarrow$ & 1 & & $\rightarrow$ & 1 \\
\hline $\begin{array}{l}\text { Pygmy nuthatch } \\
\text { (Sitta pygmaea) }\end{array}$ & & & 1 & - & & & 1 & & $!$ & 1 \\
\hline Brown creeper & - & 1 & & 1 & & $!$ & 1 & 1 & 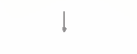 & \\
\hline Rock wren & & & 1 & & & 1 & & & & 1 \\
\hline House wren & & & 1 & 1 & & 1 & 1 & 1 & 1 & \\
\hline Winter wren & - & & & & & 1 & & 1 & & \\
\hline Golden-crowned kinglet & $\rightarrow$ & 1 & & & 1 & 1 & 1 & 1 & & \\
\hline Ruby-crowned kinglet & & 1 & & 1 & 1 & $\rightarrow$ & 1 & & ! & \\
\hline Western bluebird & & & 1 & & & 1 & 1 & & $\uparrow$ & 1 \\
\hline Mountain bluebird & & & & & & 1 & 1 & & & 1 \\
\hline Townsend's solitaire & $\rightarrow$ & $\rightarrow$ & & & - & 1 & - & & & \\
\hline Swainson's thrush & & $!$ & & & & 1 & & & & \\
\hline Hermit thrush & 1 & $!$ & 1 & $!$ & $\rightarrow$ & $\rightarrow$ & 1 & 1 & & 1 \\
\hline American robin & 1 & $\rightarrow$ & 1 & 1 & & 1 & 1 & 1 & & 1 \\
\hline Solitary vireo & - & 1 & 1 & & & - & & - & & 1 \\
\hline Warbling vireo & $\rightarrow$ & & & - & & 1 & 1 & & & \\
\hline Yellow-rumped warbler & - & $\rightarrow$ & 1 & $\rightarrow$ & $\rightarrow$ & $\rightarrow$ & 1 & 1 & - & 1 \\
\hline Townsend's warbler & & 1 & & & & 1 & & & ! & \\
\hline $\begin{array}{l}\text { Grace's warbler } \\
\text { (Dendroica graciae) }\end{array}$ & & & 1 & & & & ! & & & $!$ \\
\hline MacGillivray's warbler & & 1 & & & & $!$ & & 1 & & \\
\hline $\begin{array}{l}\text { Red-faced warbler } \\
\text { (Cardellina rubrifrons) }\end{array}$ & & & 1 & - & & & 1 & & & $!$ \\
\hline Western tanager & - & $\rightarrow$ & 1 & - & & 1 & 1 & 1 & & 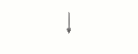 \\
\hline Black-headed grosbeak & - & & 1 & & & 1 & $\rightarrow$ & 1 & & ! \\
\hline $\begin{array}{l}\text { Rufous-sided towhee } \\
\text { (Pipilo erythrophthalmus) }\end{array}$ & 1 & & & & & & & 1 & 1 & 1 \\
\hline Chipping sparrow & & 1 & $i$ & & & 1 & - & & 1 & 1 \\
\hline $\begin{array}{l}\text { Fox sparrow } \\
\text { (Passerella iliaca) }\end{array}$ & & & & & & & & 1 & 1 & \\
\hline Dark-eyed junco & - & 1 & $\rightarrow$ & $\rightarrow$ & 1 & 1 & 1 & 1 & 1 & 1 \\
\hline Cassin's finch & & 1 & & & & 1 & & & 1 & \\
\hline Pine siskin & & $\rightarrow$ & & 1 & & $\rightarrow$ & - & 1 & - & \\
\hline
\end{tabular}




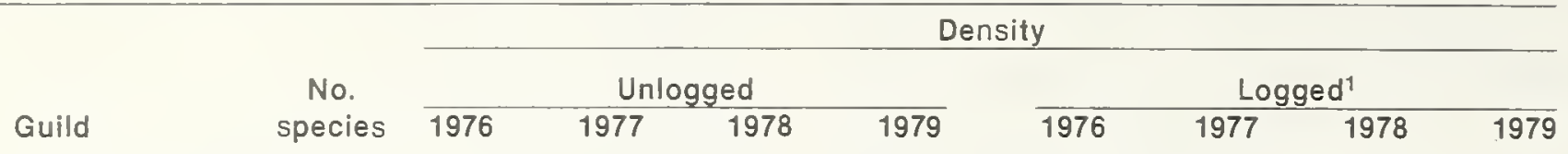

\begin{tabular}{|c|c|c|c|c|c|c|c|c|c|}
\hline & & ---- & ---- & $\cdots-\cdots$ & Pairs p & 0 acres & -- & & --- \\
\hline \multicolumn{10}{|l|}{ Foraging guild } \\
\hline Foliage foragers & 17 & 121.0 & 109.8 & 121.2 & 103.5 & 103.5 & 80.9 & 73.6 & 78.4 \\
\hline Flycatchers & 2 & 20.0 & 20.0 & 17.5 & 16.2 & 13.8 & 23.1 & 23.8 & 29.3 \\
\hline Timber drillers & 4 & 2.5 & 5.0 & 2.5 & 5.0 & 5.6 & 8.7 & 7.5 & 5.6 \\
\hline Timber gleaners & 3 & 17.5 & 21.2 & 27.5 & 37.4 & 18.7 & 9.4 & 8.8 & 6.8 \\
\hline Ground foragers & 9 & 53.7 & 56.2 & 33.7 & 41.2 & 50.6 & 74.3 & 73.0 & 82.3 \\
\hline \multicolumn{10}{|l|}{ Nesting guild } \\
\hline Conifer tree & 6 & 49.9 & 37.5 & 27.5 & 23.7 & 37.4 & 24.2 & 23.7 & 23.7 \\
\hline Conifer-deciduous tree & 6 & 39.9 & 41.2 & 48.7 & 43.6 & 33.6 & 34.2 & 35.6 & 34.2 \\
\hline Bush and small tree & 7 & 68.7 & 66.1 & 62.5 & 67.4 & 61.2 & 74.8 & 73.0 & 91.6 \\
\hline Primary cavity & 6 & 5.0 & 7.5 & 5.0 & 7.5 & 10.0 & 11.2 & 11.2 & 8.7 \\
\hline Secondary cavity & 6 & 35.0 & 39.9 & 42.5 & 47.5 & 31.8 & 26.2 & 15.6 & 23.0 \\
\hline Ground & 5 & 22.4 & 25.0 & 21.2 & 21.2 & 22.4 & 35.6 & 34.3 & 29.3 \\
\hline
\end{tabular}

${ }^{1}$ Average of bird study plots 1 and 2. Logging was done in late autumn 1976.

bush and small tree, primary cavity, secondary cavity, and ground (table 4). Bush and small-tree nesters (seven species) had the highest total density of all nesting guilds in the unlogged forest. This nesting guild reacted positively to logging. The American robin, Empidonax flycatcher, and the chipping sparrow increased most in postlogging environments; the warbling vireo was found only on logged plots.

Species that nest on the ground increased after logging. Each of the ground-nesting species represented in the study made up a greater proportion of the breeding bird population in logged areas than in the unlogged forest. The dark-eyed junco accounted for over 70 percent of the total density of the ground-nesting guild in both the logged and unlogged forest. The rock wren and winter wren were territorial only on logged plots.

The nesting guild with the largest numerical decrease in response to logging was the secondary cavity nesters, which dropped from almost 19 percent of the total breeding bird density in the unlogged forest to about 10 percent in the logged forest. Most of the decrease resulted from reductions in the abundance of the redbreasted nuthatch, mountain chickadee, and brown creeper. Although occurring in low densities, three secondary cavity nesters (house wren, western bluebird, and mountain bluebird) were found only on logged plots. Of the six secondary-cavity nesting species found during the study, three species-those that were most abundant-responded negatively to logging. and three species-those not represented in the unlogged forestresponded positively to logging.

\section{SUMMARY AND CONCLUSIONS}

These data suggest that separate components of the breeding bird community, including species populations and both foraging and nesting guilds, responded differently to structural changes in the forest vegetation caused by diameter-cut logging. Although there were slight changes in total density and standing crop biomass during the 3-year postlogging period, greater changes occurred in the species composition of the breeding bird population. Logging resulted in a positive response by six species:

\section{Empidonax flycatcher}

Townsend's solitaire

American robin

chipping sparrow

dark-eyed junco

Cassin's finch

Species responding negatively were:

mountain chickadee

red-breasted nuthatch

brown creeper

golden-crowned kinglet

Swainson's thrush

Townsend's warbler

western tanager

Densities of eight species remained relatively stable on both logged and unlogged plots:

calliope hummingbird

hairy woodpecker

northern flicker

ruby-crowned kinglet

hermit thrush

solitary vireo

Nashville warbler

pine siskin 
Bird species richness was consistently higher on logged plots than on unlogged plots and trended upward each year after logging. Ten breeding bird species were territorial only in the logged forest:

yellow-bellied sapsucker
black-backed woodpecker
olive-sided flycatcher
rock wren
house wren
winter wren
western bluebird
mountain bluebird
warbling vireo
black-headed grosbeak

All but the winter wren are characteristic of ecotonal habitats. Of those species that were territorial in the unlogged forest, only the golden-crowned kinglet was not found as a breeding bird on logged plots. There were no clear patterns in bird species diversity values either between years or between logged and unlogged plots. The evenness (equitability) component of bird species diversity tended to decline each year in postlogging environments.

Categorizing birds according to foraging or nesting behavior, or by the substrate in which foraging or nesting occurs, suggests how entire groups of species (guilds) may respond to habitat alterations. Among five recognized foraging guilds, two-the foliage foragers and the timber gleaners-were less numerous on logged plots. The timber gleaners, proportionately the most severely affected guild, dropped to about one-third prelogging densities in the third year following logging. Low timbergleaning guild densities on logged plots were probably caused by the removal of larger trees. Other guilds-the ground foragers and the flycatchers-were more numerous on logged plots. Of nine species represented in the ground-foraging guild, each was proportionately more abundant in the logged forest than in the unlogged forest. The most abundant species among the ground foragers (chipping sparrow, dark-eyed junco, Cassin's finch) were granivores. Timber-drilling species, at least in total, were a relatively stable component of the breeding bird community on both logged and unlogged plots.

Wiens (1978) noted that foliage-feeding forms numerically dominate the avifauna in North American coniferous forests, with ground-feeding, timber-foraging, and aerial feeders less important, in decreasing order. The birds of the coniferous forest we studied in west-central Idaho appear to generally fit this pattern.

Birds that nest in bushes and small trees, represented by seven species, formed the most abundant nesting guild in both the logged and unlogged forest. Bush and small-tree nesters, and those species that nest on the ground, had higher densities on logged plots. Groundnesting species, the most numerous of which was the granivorous dark-eyed junco, showed the largest increases in density. The secondary cavity-nesting guild, made up mostly of the mountain chickadee, red-breasted nuthatch, and brown creeper, decreased on logged plots. Secondary cavity nesters may have declined partly because of the lack of snag trees remaining after logging. Three secondary cavity-nesting species-the house wren, western bluebird, and mountain bluebird-were found as breeding birds only on logged plots. Total density of the primary cavity-nesting guild changed little in the logged forest.

\section{REFERENCES}

Anderson, Stanley H.; Shugart, Herman H., Jr. Habitat selection of breeding birds in an east Tennessee deciduous forest. Ecology. 55(4): 828-837; 1974.

Behle, William H. Birds of Pine Valley Mountain Region, southwestern Utah. Bulletin of the University of Utah, Biological Series. 7(5): 1-85; 1943.

Blake, John G. Influence of fire and logging on nonbreeding bird communities of ponderosa pine forests. Journal of Wildlife Management. 46(2): 404-415; 1982.

Conner, Richard N.; Adkisson, Curtis S. Effects of clearcutting on the diversity of breeding birds. Journal of Forestry. 73(12): 781-785; 1975.

Conner, Richard N.; Dickson, James G.; Locke, Brian A.; Segelquist, Charles A. Vegetation characteristics important to common songbirds in east Texas. Wilson Bulletin. 95(3): 349-361; 1983.

Daubenmire, R. A canopy-coverage method of vegetational analysis. Northwest Science. 33(1): 43-64; 1959.

Daubenmire, R.; Daubenmire, Jean B. Forest vegetation of eastern Washington and northern Idaho. Technical Bulletin 60. Pullman, WA: Washington State University, Agricultural Experiment Station; 1968. $104 \mathrm{p}$.

DeByle, Norbert V. Songbird populations and clearcut harvesting of aspen in northern Utah. Research Note INT-302. Ogden, UT: U.S. Department of Agriculture, Forest Service, Intermountain Forest and Range Experiment Station; 1981. 7 p.

Diem, Kenneth L.; Zeveloff, Samuel I. Ponderosa pine bird communities. In: DeGraff, Richard M., tech. coord. Proceedings of the workshop on management of western forests and grasslands for nongame birds; 1980 February 11-14; Salt Lake City. General Technical Report INT-86. Ogden, UT: U.S.

Department of Agriculture, Forest Service, Intermountain Forest and Range Experiment Station; 1980: 170-197.

Ford-Robertson, F. C., ed. Terminology of forest science, technology practice and products. Washington, DC: Society of American Foresters; 1971. 349 p.

Franzreb, Kathleen E.; Ohmart, Robert D. The effects of timber harvesting on breeding birds in a mixedconiferous forest. Condor. 80(4): 431-441; 1978.

Geier-Hayes, Kathleen; Ryker, Russell A. Vegetation response to helicopter logging, Silver Creek watershed, Idaho: progress report. 1983. Unpublished paper on file at: U.S. Department of Agriculture, Forest Service, Intermountain Research Station, Forestry Sciences Laboratory, Boise, ID.

Hagar, Donald C. The interrelationships of logging, birds, and timber regeneration in the Douglas-fir region of northwestern California. Ecology. 41(1): $116-125 ; 1960$. 
Hill, M. O. Diversity and evenness: a unifying notation and its consequences. Ecology. 54(2): 427-432: 1973.

International Bird Census Committee. An international standard for a mapping method in bird census work. Audubon Field Notes. 24(6): 722-726; 1970.

James, Frances C. Ordinations of habitat relationships among breeding birds. Wilson Bulletin. 83(3): 215-236; 1971.

Johnson, Ned K. The breeding avifaunas of the Sheep and Spring ranges in southern Nevada. Condor. 67(2): 93-124; 1965.

Karr, James R.; Roth, Roland R. Vegetation structure and avian diversity in several New World areas.

American Naturalist. 105(945): 423-435; 1971.

Kilgore, Bruce M. Response of breeding bird populations to habitat changes in a giant sequoia forest. American Midland Naturalist. 85(1): 135-152; 1971.

MacArthur, Robert H. Environmental factors affecting bird species diversity. American Naturalist. 98(903): 387-397; 1964.

Mannan, R. William: Meslow, E. Charles. Bird populations and vegetation characteristics in managed and old-growth forests, northeastern Oregon. Journal of Wildlife Management. 48(4): 1219-1238; 1984.

Maurer, Brian A.; McArthur, Laurence B.; Whitmore. Robert C. Effects of logging on guild structure of a forest bird community in West Virginia. American Birds. 35(1): 11-13; 1981.

Medin, Dean E. Densities and nesting heights of breeding birds in an Idaho Douglas-fir forest. Northwest Science. 59(1): 45-52; 1985.

Megahan, Walter F.; Clayton, James L. Tracing subsurface flow on roadcuts on steep, forested slopes. Soil Science Society of America Journal. 47(6): 1063-1067; 1983.

Morrison, Michael L.; Meslow, E. Charles. Avifauna associated with early growth vegetation on clearcuts in the Oregon Coast ranges. Research Paper PNW-305. Portland, OR: U.S. Department of Agriculture. Forest Service. Pacific Northwest Forest and Range Experiment Station; 1983a. 11 p.

Morrison, Michael L.; Meslow, E. Charles. Bird community structure on early-growth clearcuts in western Oregon. American Midland Naturalist. 110(1): 129-137; 1983b.

Oelke, Hans. Limitations of the mapping method. In: Ralph, C. John; Scott, J. Michael, eds. Estimating numbers of terrestrial birds: Proceedings, international symposium; 1980 October 26-31; Asilomar, CA. Studies in Avian Biology 6. Ithaca, NY: Cooper Ornithological Society; 1981: 114-118.

Ramsden, David J.; Lyon, L. Jack; Halvorson, Gary L. Small bird populations and feeding habitats-western Montana in July. American Birds. 33(1): 11-16; 1979.

Root, Richard B. The niche exploitation pattern of the Blue-gray Gnatcatcher. Ecological Monographs. 37(4): 317-350; 1967.

Salt. George William. An analysis of avifaunas in the Teton Mountains and Jackson Hole. Wyoming. Condor. 59(6): 373-393: 1957.
Scott, Virgil E.; Crouch, Glenn L.; Whelan, Jill A. Responses of birds and small mammals to clearcutting in a subalpine forest in central Colorado. Research Note RM-422. Fort Collins, CO: U.S. Department of Agriculture, Forest Service, Rocky Mountain Forest and Range Experiment Station; 1982. 6 p.

Scott, Virgil E.; Gottfried, Gerald J. Bird response to timber harvest in a mixed conifer forest in Arizona. Research Paper RM-245. Fort Collins, CO: U.S. Department of Agriculture, Forest Service. Rocky Mountain Forest and Range Experiment Station; 1983.8 p.

Steele, Robert; Pfister, Robert D.; Ryker, Russell A.; Kittams, Jay A. Forest habitat types of central Idaho. General Technical Report INT-114. Ogden, UT: U.S. Department of Agriculture, Forest Service,

Intermountain Forest and Range Experiment Station; 1981. $138 \mathrm{p}$.

Strelke, William K.; Dickson, James G. Effect of forest clear-cut edge on breeding birds in east Texas. Journal of Wildlife Management. 44(3): 559-567; 1980.

Szaro, Robert C.; Balda, Russell P. Effects of harvesting ponderosa pine on nongame bird populations. Research Paper RM-212. Fort Collins, CO: U.S. Department of Agriculture, Forest Service, Rocky Mountain Forest and Range Experiment Station; 1979. 8 p.

Thomas, Jack Ward, tech. ed. Wildlife habitats in managed forests: the Blue Mountains of Oregon and Washington. Agriculture Handbook 553. Washington, DC: U.S. Department of Agriculture. Forest Service; 1979. 512 p. [In cooperation with the Wildlife Management Institute and the U.S. Department of the Interior, Bureau of Land Management.]

Titterington, R. W.; Crawford, H. S.; Burgason, B. N. Songbird responses to commercial clear-cutting in Maine spruce-fir forests. Journal of Wildlife Management. 43(3): 602-609; 1979.

Webb, William L.; Behrend, Donald F.: Saisorn, Boonruang. Effect of logging on songbird populations in a northern hardwood forest. Wildlife Monograph 55. Washington, DC: The Wildlife Society; 1977. 35 p. [Supplement to Journal of Wildlife Management. 41(3): 1977 July.]

Wiens, John A. Nongame bird communities in northwestern coniferous forests. In: DeGraff, Richard M., tech. coord. Proceedings of the workshop on nongame bird habitat management in the coniferous forests of the western United States; 1977 February 7-9; Portland, OR. General Technical Report PNW-64. Portland, OR: U.S. Department of Agriculture, Forest Service, Pacific Northwest Forest and Range Experiment Station; 1978: 19-31.

Willson, Mary F. Avian community organization and habitat structure. Ecology. 55(5): 1017-1029; 1974.

Zamora, Benjamin A. An approach to plot sampling for canopy volume in shrub communities. Journal of Range Management. 34(2): 155-156; 1981. 
Medin, Dean E. Breeding bird responses to diameter-cut logging in west-central Idaho. Research Paper INT-355. Ogden, UT: U.S. Department of Agriculture, Forest Service, Intermountain Research Station; 1985. 12 p.

Responses of breeding bird populations to structural changes in a Douglas-fir forest caused by logging are quantitatively described. Density, diversity, standing crop biomass, foraging and nesting guild composition, and other attributes of the breeding bird community were assessed on logged and unlogged plots.

KEYWORDS: Pseudotsuga menziesii, diameter-cut logging, helicopter logging, density, diversity 


\section{INTERMOUNTAIN RESEARCH STATION}

The Intermountain Research Station provides scientific knowledge and technology to improve management, protection, and use of the forests and rangelands of the Intermountain West. Research is designed to meet the needs of National Forest managers, Federal and State agencies, industry, academic institutions, public and private organizations, and individuals. Results of research are made available through publications, symposia, workshops, training sessions, and personal contacts.

The Intermountain Research Station territory includes Montana, Idaho, Utah, Nevada, and western Wyoming. Eighty-five percent of the lands in the Station area, about 231 million acres, are classified as forest or rangeland. They include grasslands, deserts, shrublands, alpine areas, and forests. They provide fiber for forest industries, minerals and fossil fuels for energy and industrial development, water for domestic and industrial consumption, forage for livestock and wildlife, and recreation opportunities for millions of visitors.

Several Station units conduct research in additional western States, or have missions that are national or international in scope.

Station laboratories, are located in:

Boise, Idaho

Bozeman, Montana (in cooperation with Montana State University)

Logan, Utah (in cooperation with Utah State University)

Missoula, Montana (in cooperation with the University of Montana)

Moscow, Idaho (in cooperation with the University of Idaho)

Ogden, Utah

Provo, Utah (in cooperation with Brigham Young University)

Reno, Nevada (in cooperation with the University of Nevada)

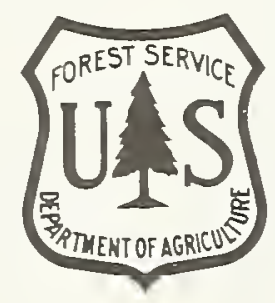

